\title{
Casein hydrolysis by Bifidobacterium longum KACC91563 and antioxidant activities of peptides derived therefrom
}

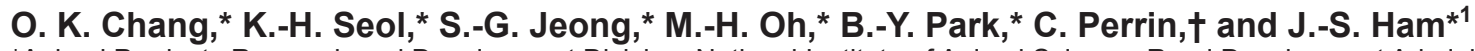 \\ ${ }^{*}$ Animal Products Research and Development Division, National Institute of Animal Science, Rural Development Administration, Suwon, \\ Gyeonggi, 441-706, Republic of Korea \\ †UR AFPA - équipe PB2P, Faculté des Sciences et Techniques, Université de Lorraine, B.P. 239, 54506 Vandoeuvre-lès-Nancy Cedex, France
}

\section{ABSTRACT}

Milk protein is a well-known precursor protein for the generation of bioactive peptides using lactic acid bacteria. This study investigated the antioxidant activity of bovine casein hydrolysate after fermentation with Bifidobacterium longum KACC91563 using the 2,2'-azinobis-(3-ethylbenzothiazoline-6-sulfonic acid) (ABTS) assay and total phenolic content (TPC). The antioxidant activities of the 24-h and 48-h hydrolysates were higher than that of the 4-h hydrolysate $(2,045.5$ and 1,629.3 $\mu M$ gallic acid equivalents, respectively, vs. $40.3 \mu M)$ in the ABTS assay. In contrast, TPC values showed activities of 43.2 and $52.4 \mu M$ gallic acid equivalents for the 4-h and 24-h hydrolysates, respectively. Three fractions $(\geq 10 \mathrm{kDa}, \geq 3$ but $<10 \mathrm{kDa}$, and $<3 \mathrm{kDa}$ ) were separated from the 24 -h hydrolysate by ultrafiltration. Among these fractions, the $<3 \mathrm{kDa}$ fraction exhibited the highest antioxidant activity (936.7 $\mu M$ ) compared with the other fractions (42.1 and 34.2 $\mu M$ for $>10 \mathrm{kDa}$ and $3-10 \mathrm{kDa}$ fractions, respectively). Through liquid chromatography-electrospray ionization-tandem mass spectrometry analysis, 2 peptides, VLSLSQSKVLPVPQK and VLSLSQSKVLPVPQKAVPYPQRDMPIQA, containing the fragment VLPVPQ that has antioxidant properties, were identified in the $<3 \mathrm{kDa}$ fraction after $24 \mathrm{~h}$ of hydrolysis. The present study demonstrates the possibility of antioxidant peptide production from bovine casein using Bifidobacterium longum.

Key words: Bifidobacterium longum, antioxidant, bioactive peptide, casein hydrolysis

\section{INTRODUCTION}

Interest in probiotic bifidobacteria, which are grampositive anaerobic bacteria found in human and animal intestinal tracts, has been increasing given their beneficial health effects including inhibition of pathogenic

Received February 12, 2013.

Accepted June 8, 2013.

${ }^{1}$ Corresponding author: hamjs@korea.kr species, reduction of colon cancer risk, protective effects on immune function, regulation of gut microflora resistance to microbial infections and serum cholesterol reduction (Leahy et al., 2005; Yu et al., 2002; Arunachalam, 1999; Collins and Gibson, 1999). In addition, probiotic bacteria play important roles in the prevention of allergic disease in early infancy (Kalliomaki et al., 2001). Given their beneficial effects, strains such as Bifidobacterium longum, Bifidobacterium breve, Bifidobacterium animalis, and Bifidobacterium bifidum are used as probiotic bacteria in the manufacture of milk products; for example, fermented milks, cheese, infant formulas, or food supplements (Davidson et al., 2000; McBrearty et al., 2001; Martín-Diana et al., 2003; Saavedra et al., 2004).

Bifidobacterium, a genus that belongs to the group of lactic acid bacteria (LAB; Yin et al., 2010; Cha et al., 2012), grows well in skim milk supplemented with milk protein hydrolysates producing lactic acid and exopolysaccharide (Prasanna et al., 2012), similar to other LAB, including Lactococcus lactis, Lactobacillus rhamnosus, Streptococcus thermophilus, Lactobacillus lactis, Lactobacillus helveticus, and Lactobacillus bulgaricus. They are auxotrophic for nitrogen sources (e.g., leucine and peptides; Mattarelli and Biavati, 1999). To obtain these nitrogen sources containing leucine, they use their proteolytic system as do other LAB. In fact, Bifidobacterium animalis ssp. lactis can hydrolyze milk protein to peptides using its proteolytic system (Janer et al., 2005). Some of these peptides have been reported to be bioactive. In general, bioactive peptides are generated from casein in different ways, such as (1) in vitro proteolysis and subsequent addition of the generated peptides to food, (2) in vivo gastrointestinal enzymatic digestion by microbial enzymes in the gastrointestinal tract of organisms, or (3) by lactic acid bacteria during fermentation (Korhonen, 2009). It is well known that milk proteins such as casein and whey proteins are precursor proteins that generate bioactive peptides released by the proteolytic system of LAB. Milk-based bioactive peptides released by LAB are well documented in the literature (Hayes et al., 2007; Sadat-Mekmene et al., 2011; Chang et al., 2012; Miclo 
et al., 2012). For example, the VPP and IPP peptides from $\beta$-casein are best known for their angiotensinconverting enzyme (ACE) inhibition activity, and the fermented milks Calpis (Calpis Co. Ltd., Tokyo, Japan) and Evolus (Valio Ltd., Helsinki, Finland) containing the VPP and IPP peptides are commercially available (Korhonen, 2009). In addition, many peptides generated from casein by microbial fermentation are ACE inhibitory peptides, in contrast to other bioactive peptides (e.g., antioxidant peptides, opiates, antimutagens, immunomodulatory peptides, antimicrobial peptides, or peptides with mineral binding activity).

Among the various bioactive peptides, those with antioxidant properties are also important because increased levels of reactive oxygen species such as free radicals cause cancer, DNA damage, diabetes, cardiovascular diseases, allergies, and aging (Wolff et al., 1991; Beckman and Ames, 1998; Agerholm-Larsen et al., 2000). However, the defense systems of organisms are not sufficient to prevent oxidative damage (Kullisaar et al., 2003). Therefore, other antioxidant substances originating from plants or food, particularly milk protein from dairy products, may be provided to organisms as a supplement to prevent such damage.

However, production of bioactive peptides by Bifidobacterium is rarely documented in the literature, except for research on the hypocholesterolemic effect of casein hydrolysate after incubation with Bifidobacterium animalis ssp. lactis strain Bb12 and of yogurt containing Bifidobacterium pseudocatenulatum G4 (or Bifidobacterium longum BB536), reported by Alhaj et al. (2010) and Al-Sheraji et al. (2012), respectively. On the contrary, we can find no reports to date of other bioactive peptides including antioxidant peptides generated by Bifidobacterium strains. For this reason, the objective of this work was to investigate potential antioxidant peptides released from bovine casein after hydrolysis by Bifidobacterium longum KACC91563.

\section{MATERIALS AND METHODS}

\section{Materials}

Chemical reagents including 2,2'-azinobis-(3-ethylbenzothiazoline-6-sulfonic acid) (ABTS), gallic acid, Folin-Ciocalteu reagent, and the chromogenic substrate lysine-p-nitroanilic acid (Lys-pNA) were purchased from Sigma-Aldrich (St. Louis, MO). All other chemicals used were of analytical grade.

\section{Isolation and Retrieval of Bifidobacterium longum KACC91563}

Matrix and standard preparation and identification of the isolate from infant feces were performed using a previously described method (Ham et al., 2011). After isolation of this strain, Bifidobacterium longum KACC91563 was grown in de Man, Rogosa, and Sharpe (MRS) broth (BD Biosciences, San Jose, CA) containing cysteine $(0.05 \%$, final concentration), and the cells (bacteria) were harvested by centrifugation (Beckman Coulter, Brea, CA) at $3,200 \times g$ for $30 \mathrm{~min}$ at $4^{\circ} \mathrm{C}$. The cells were stored in reconstituted skim milk (10\% wt/ vol) at $-80^{\circ} \mathrm{C}$.

\section{Growth Conditions}

Before the experiment, B. longum was grown overnight in skim milk at $37^{\circ} \mathrm{C}$, according to the method previously described (Ruiz et al., 2009). Bifidobacterium longum (initial inoculum, $1 \%$ ) was grown at $37^{\circ} \mathrm{C}$ in $50 \mathrm{~mL}$ of MRS broth supplemented with cysteine (final concentration, 1\%).

\section{Casein Hydrolysis}

Bifidobacterium longum (initial inoculum, 1\%) was grown at $37^{\circ} \mathrm{C}$ in $50 \mathrm{~mL}$ of MRS broth supplemented with cysteine (final concentration, 1\%) to the exponential phase ( $\mathrm{pH}$ 5.1). Then, the cells were harvested by centrifugation (Beckman Coulter) at 3,200 $\times g$ for $15 \mathrm{~min}$ at $20^{\circ} \mathrm{C}$ and washed twice with $0.05 \mathrm{M}$ sodium phosphate buffer, $\mathrm{pH}$ 7.0, using the same centrifugation conditions. The cells were suspended in $5 \mathrm{~mL}$ of the same buffer and mixed with $20 \mathrm{~mL}$ of $0.1 \%$ (wt/vol) bovine casein (Sigma-Aldrich) solution as a substrate. The cells were then incubated at $37^{\circ} \mathrm{C}$ for $0,4,24$, and $48 \mathrm{~h}$, and the supernatant fractions were immediately collected after centrifugation at 13,200 $\times g$ for $10 \mathrm{~min}$ at $4^{\circ} \mathrm{C}$ and filtered $(0.45-\mu \mathrm{m}$ filter $)$. The hydrolysates obtained were stored at $-20^{\circ} \mathrm{C}$ before their use in the following experiments.

\section{Peptidase Activity}

To verify cell surface peptidase and cell lysis activity of $B$. longum, a peptidase activity assay was performed using the chromogenic substrate Lys-pNA (Miclo et al., 2012). The substrate was prepared at a concentration of $2 \mathrm{mM}$ in $0.05 M$ sodium phosphate buffer, $\mathrm{pH}$ 7.0. Bifidobacterium longum grown to the exponential phase (pH 5.1) was harvested by centrifugation at 3,200 $\times g$ for $5 \mathrm{~min}$ at $20^{\circ} \mathrm{C}$. The cell pellet was washed 2 times with $0.05 M$ sodium phosphate buffer, $\mathrm{pH}$ 7.0, and then resuspended in the same buffer. One hundred microliters of cell suspension was then mixed with 1 $\mathrm{mL}$ of Lys-pNA solution and incubated for $1 \mathrm{~h}$ at $37^{\circ} \mathrm{C}$. The reaction mixture was centrifuged at $13,200 \times g$ at $4^{\circ} \mathrm{C}$ for 10 min to pellet the cells, and the absorbance 
of the supernatant was determined at $410 \mathrm{~nm}$ using a SpectraMax spectrophotometer (Molecular Devices, Sunnyvale, CA).

\section{Electrophoresis}

Sodium dodecyl sulfate-PAGE was performed as previously described (Egito et al., 2002; Chang et al., 2012) using a 5\% stacking gel and 15\% separating gel. Twenty microliters (about $10 \mu \mathrm{g}$ of hydrolysate) was loaded into each well along with broad-range standard molecular mass markers $(6,17,26,34,43,55,70,95$, 130 , and $170 \mathrm{kDa})$. After migration, the gel was stained in $0.1 \%$ Coomassie Blue R-250 solution containing 2\% (wt/vol) TCA and 50\% (vol/vol) ethanol. The gel was destained using a mixture of $50 \%$ methanol, $10 \%$ acetic acid, and $40 \%$ water.

\section{Reverse-Phase HPLC}

To confirm the hydrolysis of bovine casein, the hydrolysates were separated on a Zorbax 300SB-C18 analytical column $(3.0 \times 150 \mathrm{~mm}$, diameter $3.5 \mu \mathrm{m}$, Agilent, Santa Clara, CA) connected to an HPLC system (Jasco, Oklahoma City, OK). Fifty microliters of sample were injected into the column and eluted at $30^{\circ} \mathrm{C}$ using a linear gradient ( 5 to $50 \%$ ) over $90 \mathrm{~min}$. The flow rate was $0.25 \mathrm{~mL} / \mathrm{min}$, and peptides were detected by UV absorption at $215 \mathrm{~nm}$.

\section{Antioxidant Activity: Radical Scavenging Assay}

Free radical scavenging activity of the casein hydrolysate was determined using ABTS radical cation $\left(\right.$ ABTS $\left.^{+\bullet}\right)$ according to previously described method with minor modifications (Re et al., 1999; Sadat et al., 2011). To generate the $\mathrm{ABTS}^{+\bullet}$ radical, ABTS and potassium persulfate were prepared at final concentrations of 7 and $2.45 \mathrm{~m} M$, respectively, and incubated for $16 \mathrm{~h}$ in the dark at $30^{\circ} \mathrm{C}$. Using a spectrophotometer (Molecular Devices), the $\mathrm{ABTS}^{+\bullet}$ radical was adjusted to an absorbance of $0.70 \pm 0.02$ at $735 \mathrm{~nm}$ by diluting with distilled water. Fifty microliters of casein hydrolysate was mixed with $950 \mu \mathrm{L}$ of the $\mathrm{ABTS}^{+}$radical solution. The decrease of the absorbance was monitored at $735 \mathrm{~nm}$ after $30 \mathrm{~min}$ at $30^{\circ} \mathrm{C}$. All assays were carried out in triplicate, and the values represent the means. A standard curve was prepared using various concentrations $(1,2,20,40,60,80,100$, and $120 \mu M)$ of gallic acid. For standard curve calculation, the percentage antioxidant activity was calculated as follows: Scavenging activity $(\%)=\left[\left(\mathrm{A}_{\text {control }}-\mathrm{A}_{\text {sample }}\right) / \mathrm{A}_{\text {control }}\right] \times 100$, where $\mathrm{A}_{\text {control }}$ represents the initial ABTS absorbance. The radical scavenging activity of the casein hydroly- sates was calculated from the equation of the standard curve based on gallic acid and expressed as micromoles of gallic acid equivalent (GE).

\section{Antioxidant Activity: Determination of Total Phenolic Contents}

Total phenolic content (TPC) measurement was followed by the previously described method (Singleton and Rossi, 1965; Yu et al., 2006; Yang et al., 2008) with minor modifications. For this purpose, a volume of $60 \mu \mathrm{L}$ of sample was mixed with $60 \mu \mathrm{L}$ of the FolinCiocalteu solution, which was prepared by mixing 1 volume of Folin-Ciocalteu reagent with 2 volumes of distilled water. Finally, $60 \mu \mathrm{L}$ of $10 \%$ sodium carbonate $\left(\mathrm{Na}_{2} \mathrm{CO}_{3}\right)$ solution was added in this mixture. After incubation of the mixture at room temperature for $1 \mathrm{~h}$ in the dark, absorbance at $700 \mathrm{~nm}$ was measured using a spectrophotometer (Molecular Devices). All assays were carried out in triplicate and the values represent the means. A standard curve was prepared using various concentrations $(1,2,20,40,60,80,100$, and 120 $\mu M)$ of gallic acid. The TPC of the casein hydrolysates was calculated from the equation of the standard curve based on gallic acid and expressed as micromoles of GE.

\section{Fractionation of Hydrolysates}

Fractions with molecular weight cutoffs of 10 and 3 $\mathrm{kDa}$ were separated using an ultrafiltration membrane system (Millipore, Billerica, MA).

\section{Mass Spectrometry Analysis}

Liquid chromatography tandem MS (LC-MS/ MS) experiments were carried out using an integrated system consisting of autoswitching nano pump, autosampler (Tempo nano LC system, MDS Sciex, Toronto, Ontario, Canada) and a hybrid quadrupole-time-offlight (TOF) tandem mass spectrometer (QStar Elite, Applied Biosystems, Foster City, CA) equipped with a nano-electrospray ionization (ESI) source and fitted with a fused-silica emitter tip (New Objective, Woburn, MA). This experiment was performed at National Instrumentation Center for Environmental Management (NICEM) of Seoul National University in Korea. Fractions $(2 \mu \mathrm{L})$ were injected into LC-nano ESI-MS/MS system. Solvent A consisted of water/acetonitrile (98:2, $\mathrm{vol} / \mathrm{vol}$ ) with $0.1 \%$ formic acid for the high aqueous mobile phase. Samples were first trapped on a Zorbax 300SB-C18 trap column $(300-\mu \mathrm{m}$ i.d. $\times 5 \mathrm{~mm}, 5-\mu \mathrm{m}$ particle size, $100 \AA$ pore size, part number 5065-9913; Agilent Technologies, Santa Clara, CA) and washed for 
6 min with $98 \%$ solvent A [water/ACN $(98: 2, \mathrm{vol} / \mathrm{vol})$, $0.1 \%$ formic acid] and $2 \%$ solvent B [water/ACN (2:98, $\mathrm{vol} / \mathrm{vol}), 0.1 \%$ formic acid] at a flow rate of $5 \mu \mathrm{L} / \mathrm{min}$, and then separated on a Zorbax 300SB-C18 capillary column $(75-\mu \mathrm{m}$ i.d. $\times 150 \mathrm{~mm}, 3.5-\mu \mathrm{m}, 100 \AA$ pore size, part number 5065-9911; Agilent Technologies) at a flow rate of $300 \mathrm{~nL} / \mathrm{min}$. The $\mathrm{LC}$ gradient was run at 2 to $35 \%$ solvent B over $30 \mathrm{~min}$, and then from 35 to $90 \%$ over $10 \mathrm{~min}$, followed by $90 \%$ solvent B for $5 \mathrm{~min}$, and finally $5 \%$ solvent B for $15 \mathrm{~min}$. Resulting peptides were electrosprayed through a coated silica tip (FS36020-10-N20-C12, PicoTip emitter, New Objective) at an ion spray voltage of $2,000 \mathrm{eV}$. Mass data were acquired automatically using Analyst QS 2.0 software (Applied Biosystems). The range of $\mathrm{m} / \mathrm{z}$ was 200 to 2,000 .

\section{RESULTS AND DISCUSSION}

\section{Production of Peptides from Casein Hydrolysis of Bifidobacterium longum}

Bifidobacterium longum was grown to exponential phase in MRS broth containing cysteine. The cells were retrieved and incubated with bovine casein in $0.05 \mathrm{M}$ sodium phosphate buffer, $\mathrm{pH}$ 7.0. Casein hydrolysates were obtained after $0,4,24$, and $48 \mathrm{~h}$ of hydrolysis by centrifugation and filtration $(0.45 \mu \mathrm{m})$. Bovine casein was solubilized in $0.05 \mathrm{M}$ sodium phosphate buffer at $\mathrm{pH}$ 7. This $\mathrm{pH}$ is similar to that of milk (6.6-6.8), indicating the similar environment (Miclo et al., 2012).

The casein hydrolysates were analyzed by SDSPAGE to verify the hydrolysis patterns after the abovementioned incubation periods. Figure 1 shows the hydrolysis of bovine casein by $B$. longum after 24 and $48 \mathrm{~h}$ of incubation, in particular, of $\beta$-casein compared

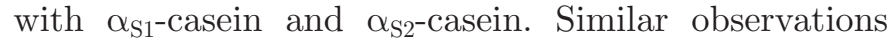
have been reported in several studies on LAB in the literature, including Lc. lactis, Lb. rhamnosus, Strep. thermophilus, Lb. lactis, Lb. helveticus, and Lb. bulgaricus (Kok et al., 1988; Shahbal et al., 1993; Gilbert et al., 1996; Fernandez-Espla et al., 2000; Pastar et al., 2003; Espeche Turbay et al., 2009; Sadat-Mekmene et al., 2011). Thus, in the case of B. longum, as with other $\mathrm{LAB}, \beta$-casein is preferentially degraded compared with $\alpha_{\mathrm{S} 1}$-casein and $\alpha_{\mathrm{S}^{2}}$-casein. The different accessibilities may be explained by structural differences between individual caseins. Compared with other caseins, $\beta$-casein is more unstructured and more accessible to cleavage, and is therefore hydrolyzed to a greater extent (Holt and Sawyer, 1993; Kumosinski et al., 1993; SadatMekmene et al., 2011).

This observation of casein degradation was confirmed by HPLC profiles. As shown in Figure 2, the number of peaks increased with incubation time, especially after

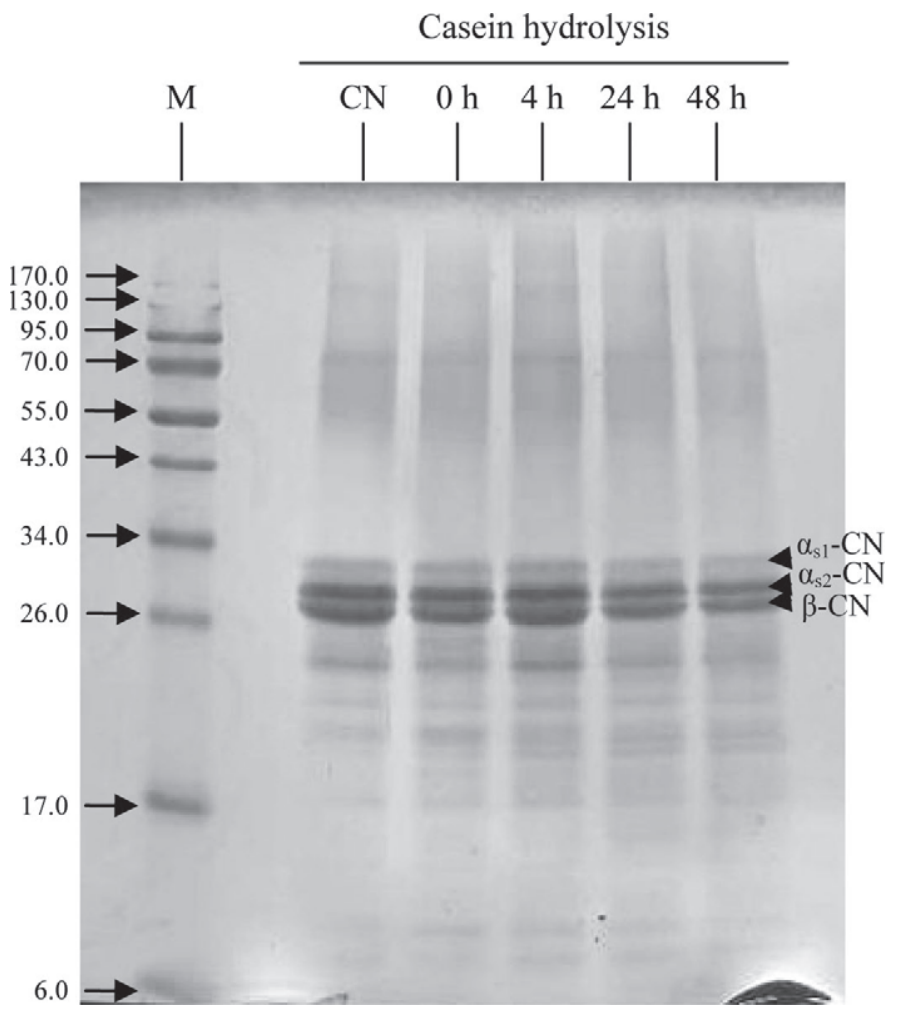

Figure 1. Electrophoretic patterns of bovine casein hydrolyzed by Bifidobacterium longum KACC91563. Twenty microliters (about 10 $\mu \mathrm{g}$ of hydrolysate) was loaded in each well. M denotes protein molecular weight markers. Cells were grown in de Man, Rogosa, and Sharpe broth until the $\mathrm{pH}$ reached 5.1 and then were collected after centrifugation. Caseins were solubilized at $0.1 \%$ (wt/vol) in $0.05 \mathrm{M} \mathrm{Na}$ phosphate buffer, $\mathrm{pH}$ 7.0. One volume of cell suspension of $B$. longum was incubated with 4 volumes of caseins at $37^{\circ} \mathrm{C}$ and the hydrolysate used as a sample was recovered at each incubation time: (a) $0 \mathrm{~h}$, (b) 4 h, (c) $24 \mathrm{~h}$, and (d) $48 \mathrm{~h}$.

hydrolysis for 24 and $48 \mathrm{~h}$, in contrast to the minimal casein degradation seen at elution times under about $40 \mathrm{~min}$ at $0 \mathrm{~h}$ of incubation. This indicates that the casein is well degraded by $B$. longum in the present study, although no protease activity was detected for B. longum using the chromogenic substrate (Suc-AlaAla-Pro-Phe-pNa) and zymography (data not shown). This has also been proven by Janer et al. (2005), who reported the absence of protease activity of $B$. animalis ssp. lactis in whole cells, the cell wall-bound fraction, and cell extracts. In some strains such as B. longum DJO10A (accession number YP_001955201.1) or B. longum ssp. infantis ATCC 15697 (accession number YP_002322571.1), a subtilisin-like serine protease is present, but there are no reports of the genetic and biochemical characterization and identification for this protease, similar to the cell envelope protease (CEP) of LAB. In fact, some LAB use their CEP to hydrolyze milk protein for growth (Savijoki et al., 2006). 
On the other hand, whole cells in the B. animalis strain can degrade casein after $24 \mathrm{~h}$ of incubation; this could be a result of cell lysis, causing degradation of casein by enzymes in the intracellular fraction, such as peptidase $\mathrm{O}$ (pep $\mathrm{O}$ ) with $67.4 \%$ identity in $B$. longum (Janer et al., 2005). However, we observed no peptidase activity using Lys-pNA in cell suspensions without casein after $0,4,24$, and $48 \mathrm{~h}$ of incubation in the present study, which indicates the absence of cell lysis. Therefore, the degradation of casein by B. long- $u m$ was not due to intracellular peptidases released by cell lysis. However, peptidase activity using Lys-pNA was detected in the whole cell fraction [absorbance at $410 \mathrm{~nm}\left(\mathrm{~A}_{410}\right)=0.921$, which corresponds to about $38.4 \mathrm{nmol} / \mathrm{min}$ per $\mathrm{mL}$ of $\mathrm{pNA}$ released, calculated by Lambert-Beer law's equation]. This means that casein could be hydrolyzed by potential peptidases linked to the cell wall or another proteolytic system. Further study is needed to identify and characterize this peptidase.
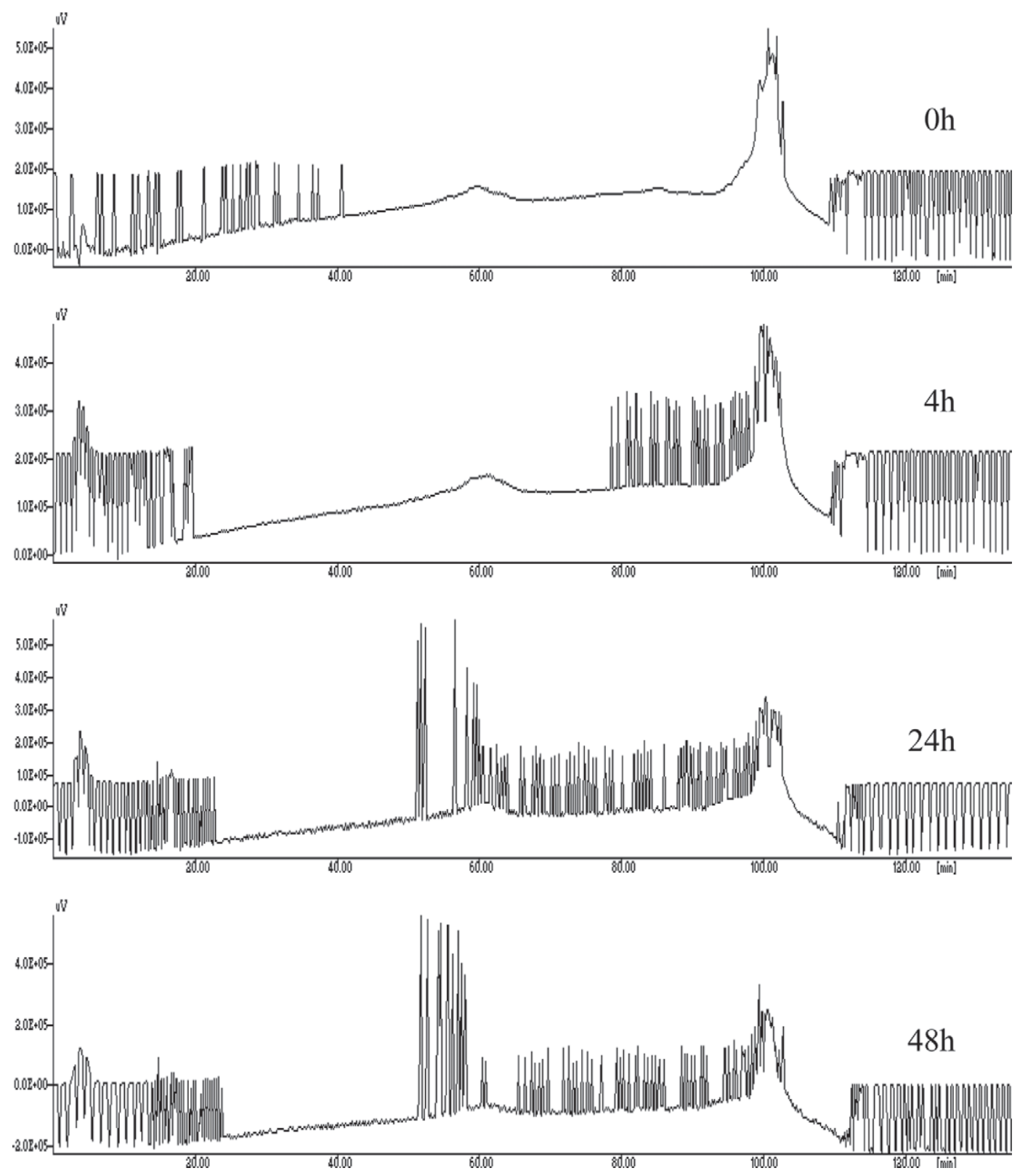

Figure 2. Reverse phase-HPLC analysis of bovine casein $(0.1 \%$, wt/vol) hydrolysis by fermentation of Bifidobacterium longum KACC9156. Fifty microliters of sample was injected onto the column and eluted at $30^{\circ} \mathrm{C}$ by using a linear gradient $(5$ to $50 \%)$ of solvent B (0.1\% trifluoroacetic acid in acetonitrile) within $90 \mathrm{~min}$. The flow rate was $0.25 \mathrm{~mL} / \mathrm{min}$, and peptides were detected by UV absorption at $215 \mathrm{~nm}$. 
A)

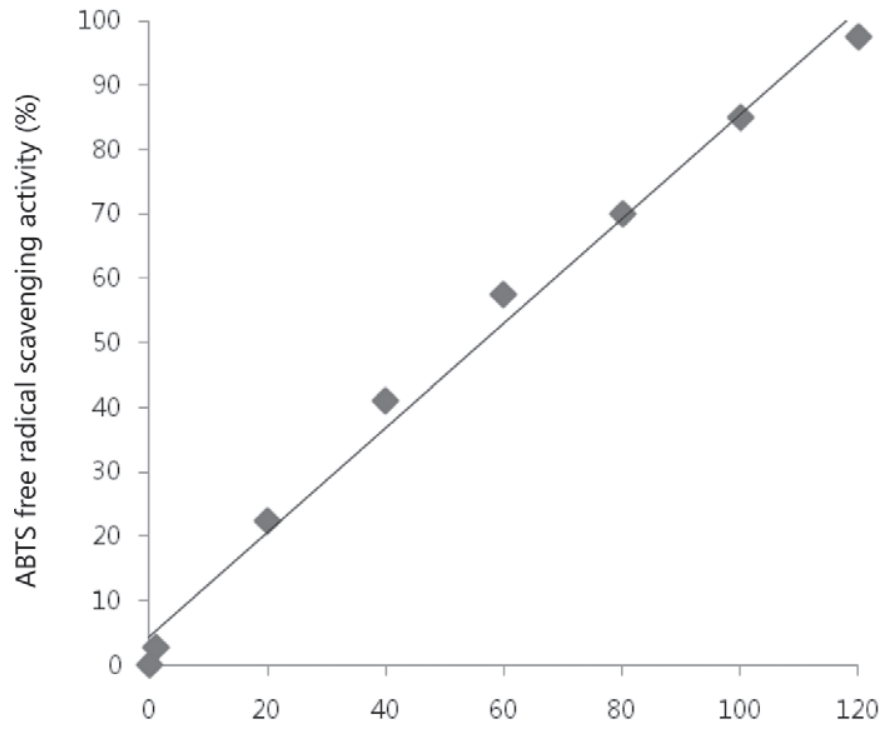

B)

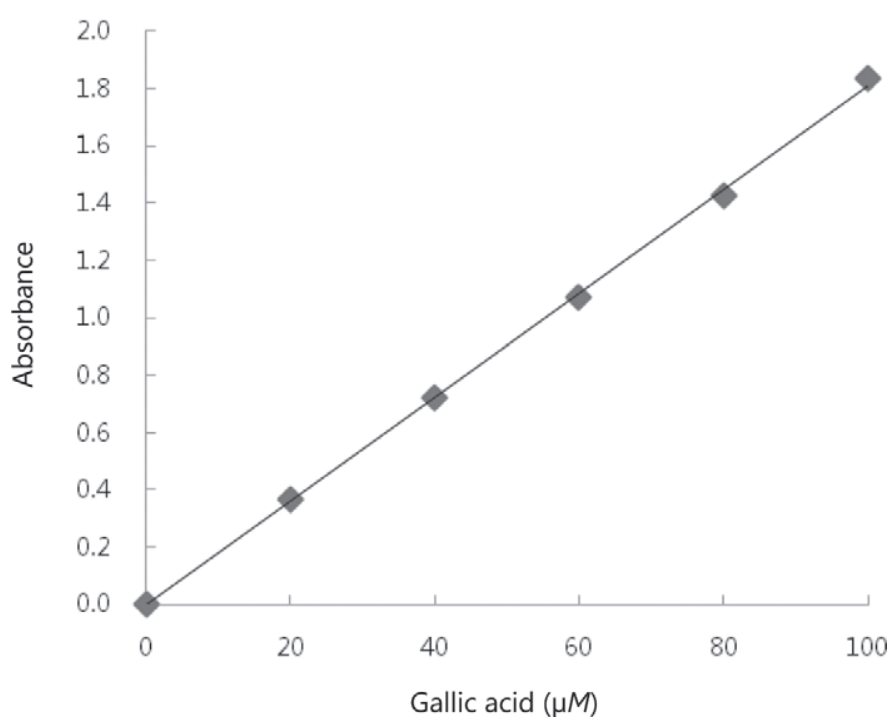

Figure 3. Relationship between concentration and ABTS [2,2'-azinobis-(3-ethylbenzothiazoline-6-sulfonic acid)] free radical scavenging capacity (A) and total phenolic contents (B) of gallic acid as a standard. Data are expressed as the average value of triplicates. The equation for this curve is $\mathrm{y}=0.8106 \mathrm{x}+4.377$, with an $\mathrm{R}^{2}$ value of 0.99 for ABTS free radical scavenging capacity and $\mathrm{y}=0.0182 \mathrm{x}-$ $0.0039 ; \mathrm{R}^{2}=0.99$ for total phenolic contents.

\section{Investigation of Antioxidant Activity in Hydrolyzed Fractions Using ABTS Radical Scavenging Capacity}

To investigate the free radical scavenging properties of casein hydrolysates by $B$. longum according to incubation times, the ABTS method, which is widely used to investigate free radical scavenging properties for antioxidant activity, was adapted from a previously described method (Re et al., 1999; Sadat et al., 2011). In the present study, none of the casein hydrolysate fractions were detected with the 1,1-diphenyl-2-picrylhydrazyl (DPPH) assay, another free radical scavenging activity assay (data not shown). This could be due to the nature of compounds in the sample. Arnao (2000) reported that the ABTS radical is soluble in aqueous and organic media, whereas the $\mathrm{DPPH}$ radical dissolves only in organic media. Therefore, in this study, the hydrolysate fractions were analyzed using the ABTS radical scavenging method.

Various concentrations of gallic acid, a strong antioxidant molecule, were used to generate the standard curve. The reaction mixture (gallic acid and ABTS cation radical) was incubated at $30^{\circ} \mathrm{C}$ for $30 \mathrm{~min}$. The linear standard curve with a range from 0 to $120 \mu M$ gallic acid is presented in Figure 3A. From the equation of the standard curve, the $\mathrm{IC}_{50}$ value (the concentration that inhibits the activity by $50 \%$ ) was $56 \mu M$ gallic acid.

The free radical scavenging properties of casein hydrolysates following different incubation periods are presented in Table 1. Antioxidant properties improved with increasing duration of hydrolysis with $B$. longum. The 24- and 48-h hydrolysates exhibited higher antioxidant capacities than did the other hydrolysates. Their GE values deduced from the standard curve equation of gallic acid were 2,045.5 and 1,629.3 $\mu \mathrm{M}$, respectively (Table 1). A blank sample (casein solution after 24-h incubation without $B$. longum cells) was measured as a control for casein autolysis and showed a GE value similar to that seen at $0 \mathrm{~h}$. Thus, it appears that casein autolysis does not result in antioxidant activity at 4, 24, or $48 \mathrm{~h}$. The different GE values may be due to more extensive hydrolysis at $48 \mathrm{~h}$ than at $24 \mathrm{~h}$. Consequently, the smaller peptides generated after $48 \mathrm{~h}$ of hydrolysis may lack antioxidant activity.

The GE values at 0 and $4 \mathrm{~h}$ of hydrolysis were 120.1 and $140.3 \mu M$, respectively (Table 1 ), which corresponded to 5.8 and $6.8 \%$ ( 0 and $4 \mathrm{~h}$ vs. $24 \mathrm{~h}$ ) and 7.3 and $8.6 \%$ ( 0 and $4 \mathrm{~h}$ vs. $48 \mathrm{~h}$ ) of the later values, respectively. Thus, the 24 -h and 48 -h hydrolysates may contain antioxidant peptides (or antioxidant substances) from bovine casein.

\section{Investigation of TPC in Hydrolyzed Fractions}

Phenolic content analysis was performed to detect phenolic amino acids in the peptides and to confirm antioxidant activity. Gallic acid was used to generate the standard curve. The linear standard curve with a range from 0 to $100 \mu M$ gallic acid is presented in Figure $3 \mathrm{~B}$. The GE values of TPC in the $<3 \mathrm{kDa}$ fraction correspond to $6.5,43.2,52.4$, and $20.2 \mu M$ for $0,4,24$, and $48 \mathrm{~h}$, respectively (Table 1), showing low GE val- 
Table 1. Antioxidant activities in gallic acid equivalents $(\mathrm{GE}, \mu M)$ of casein hydrolysates after incubation with Bifidobacterium longum KACC91563

\begin{tabular}{lrrrr}
\hline & \multicolumn{4}{c}{ Incubation time (h) } \\
\cline { 2 - 4 } Item $^{1}$ & \multicolumn{1}{c}{ ( } & \multicolumn{1}{c}{4} \\
\hline ABTS free radical scavenging capacity & 120.1 & 140.3 & $2,045.5$ & $1,629.3$ \\
Total phenolic content (TPC) & 6.5 & 43.2 & 52.4 & 20.2 \\
\hline${ }^{1}$ ABTS $=2,2^{\prime}$-azinobis-(3-ethylbenzothiazoline-6-sulfonic acid); gallic acid equivalents were calculated using \\
the standard curve equation after triplicate measurement of absorbance (at 735 nm for ABTS and at 700 nm \\
for TPC).
\end{tabular}

ues compared with those seen with ABTS scavenging activity. Unlike the results of ABTS radical scavenging activity, the hydrolysate after $4 \mathrm{~h}$ of incubation had a high GE value $(43.5 \mu M)$ compared with that at 48 $\mathrm{h}(20.2 \mu M)$. Regardless of the antioxidant activity measurement method, the highest GE value was seen for the hydrolysate after $24 \mathrm{~h}$ incubation. This fraction had a relatively low content of peptides with phenol groups (e.g., tyrosine) compared with other antioxidant peptides detected by ABTS scavenging activity.

\section{Antioxidant Properties in Fractions Separated According to Molecular Weight by Ultrafiltration}

For further analysis, the 24-h hydrolysate was fractionated according to molecular weight using ultrafiltration. Using cut-off values of 10 and $3 \mathrm{kDa}$, the $24-\mathrm{h}$ hydrolysate was separated into 3 fractions $(>10 \mathrm{kDa}$, $3-10 \mathrm{kDa}$, and $<3 \mathrm{kDa}$ ). The $<3 \mathrm{kDa}$ fraction exhibited the highest free radical scavenging capacity after 10fold dilution (80.3\%), corresponding to $936.7 \mu M \mathrm{GE}$ (Table 2). The capacities of the $>10 \mathrm{kDa}$ and $3-10 \mathrm{kDa}$ fractions were 38.5 and $32.1 \%$, respectively, which corresponded to 42.1 and $34.2 \mu M \mathrm{GE}$, respectively. Thus, potential antioxidant peptides derived from bovine casein hydrolysis with $B$. longum may be present in the $<3 \mathrm{kDa}$ fraction, given that most milk protein-derived bioactive peptides with antioxidant properties reported in the literature are small $(<10 \mathrm{AA})$. Thus, this fraction was used for the identification of peptides using LC-ESI-MS/MS analysis.

\section{Identification of Peptides Generated from Bovine Casein in the $<3$ kDa Fraction}

The peptides generated from bovine casein were further identified by LC-ESI-quantitative time-of-flight MS analysis. In the $<3 \mathrm{kDa}$ fraction, the peptides were generated to a greater extent from $\beta$-casein than from other caseins $(\alpha$-casein and $\kappa$-casein), consistent with results of the SDS-PAGE and reversed phaseHPLC profiles. Nineteen peptides were generated from $\beta$-casein, but only 12 were generated from $\alpha_{\mathrm{S}^{1}}$-casein and 2 from $\kappa$-casein (Table 3 ).

$\beta$-Casein, compared with other caseins, could be a preferred substrate for B. longum as for LAB (Juillard et al., 1995; Sadat-Mekmene et al., 2011; Chang et al., 2012; Miclo et al., 2012). To hydrolyze casein, LAB use their CEP, which is linked to peptidoglycan at the cell wall by the action of sortase (Chang et al., 2012). To date, 6 types of CEP in LAB have been reported, including PrtP for Lc. lactis, PrtR for Lb. rhamnosus, PrtS for Strep. thermophilus, PrtL for Lb. lactis, PrtH for Lb. helveticus, and PrtB for Lb. bulgaricus; these facilitate bacterial growth themselves and produce peptides (Savijoki et al., 2006; Espeche Turbay et al., 2009). As mentioned above, in the case of B. longum, no CEP activity was detected in the cell wall using zymography and using the chromogenic substrate Suc-Ala-Ala-ProPhe-pNA (Sigma). Similar to B. longum in the present study, the Strep. thermophilus CNRZ1066 strain without the gene encoding CEP did not hydrolyze casein. This strain also had no intracellular peptidase activity

Table 2. Antioxidant activities of casein hydrolysate fractions obtained after $24 \mathrm{~h}$ of hydrolysis by Bifidobacterium longum KACC91563

\begin{tabular}{lccc}
\hline & \multicolumn{3}{c}{ Fraction } \\
\cline { 2 - 4 } Activity & $\geq 10 \mathrm{kDa}$ & $\geq 3$ but $<10 \mathrm{kDa}$ & $<3 \mathrm{kDa}^{2}$ \\
\hline Absorbance at $735 \mathrm{~nm}$ & $0.478 \pm 0.009$ & $0.523 \pm 0.020$ & $0.185 \pm 0.011$ \\
Scavenging activity $(\%)$ & 38.5 & 32.1 & 80.3 \\
$\mathrm{GE}^{3}(\mu M)$ & 42.1 & 34.2 & 936.7 \\
\hline${ }^{1}$ All assays were carried out in triplicate. & \\
${ }^{2}$ Sample was diluted 10-fold. & & \\
${ }^{3} \mathrm{GE}=$ gallic acid equivalents calculated using the standard curve equation.
\end{tabular}


Table 3. Casein-derived peptides identified by liquid chromatography-electrospray ionization-tandem mass spectrometry in the $<3 \mathrm{kDa}$ fraction of the 24-h hydrolysate obtained by fermentation of Bifidobacterium longum KACC91563 ${ }^{1}$

\begin{tabular}{|c|c|c|c|c|c|c|}
\hline \multirow[b]{2}{*}{ Casein } & \multirow[b]{2}{*}{ Peptide sequence } & \multicolumn{2}{|c|}{ Precursor } & \multicolumn{3}{|c|}{ Theoretical } \\
\hline & & MW & $m / z$ & MW & $m / z$ & $z$ \\
\hline \multirow{11}{*}{$\beta-\mathrm{CN}$} & f127-138, LTDVENLHLPLP & $1,359.7151$ & 680.8648 & $1,359.7399$ & 680.8772 & 2 \\
\hline & f129-138, DVENLHLPLP & $1,145.5861$ & 573.8003 & $1,145.6080$ & 573.8113 & 2 \\
\hline & f139-154, LLQSWMHQPHQPLPPT & $1,924.9486$ & 642.6568 & $1,924.9618$ & 642.6612 & 3 \\
\hline & f162 176, VLSLSQSKVLPVPQK & $1,621.9622$ & 541.6613 & $1,621.9767$ & 541.6662 & 3 \\
\hline & f177-190, AVPYPQRDMPIQAF & $1,631.7853$ & 816.8999 & $1,631.8130$ & 816.9138 & 2 \\
\hline & f190-202, FLLYQEPVLGPVR & $1,529.8336$ & 765.9241 & $1,529.8606$ & 765.9376 & 2 \\
\hline & f191-209, LLYQEPVLGPVRGPFPIIV & $2,106.2126$ & 703.0782 & $2,106.2241$ & 703.0820 & 3 \\
\hline & f191-206, LLYQEPVLGPVRGPFP & $1,780.9554$ & 891.4850 & $1,780.9875$ & 891.5011 & 2 \\
\hline & f191-202, LLYQEPVLGPVR & $1,382.7690$ & 692.3918 & $1,382.7922$ & 692.4034 & 2 \\
\hline & f192-209, LYQEPVLGPVRGPFPIIV & $1,993.1140$ & 997.5643 & $1,993.1400$ & 997.5773 & 2 \\
\hline & f193-206, YQEPVLGPVRGPFP & $1,554.7985$ & 778.4065 & $1,554.8195$ & 778.4170 & 2 \\
\hline \multirow[t]{12}{*}{$\alpha_{S^{-}-} \mathrm{CN}$} & f8-23, HQGLPQEVLNENLLRF & $1,905.9950$ & 636.3389 & $1,906.0061$ & 636.3427 & 3 \\
\hline & f8-22, HQGLPQEVLNENLLR & $1,758.9219$ & 587.3146 & $1,758.9376$ & 587.3198 & 3 \\
\hline & f10-23, GLPQEVLNENLLRF & $1,640.8618$ & 821.4382 & $1,640.8886$ & 821.4516 & 2 \\
\hline & f10-22, GLPQEVLNENLLR & $1,493.8003$ & 747.9074 & $1,493.8202$ & 747.9174 & 2 \\
\hline & f11-23, LPQEVLNENLLRF & $1,583.8389$ & 792.9267 & $1,583.8672$ & 792.9409 & 2 \\
\hline & f11-22, LPQEVLNENLLR & $1,436.7737$ & 719.3941 & $1,436.7987$ & 719.4066 & 2 \\
\hline & f12-22, PQEVLNENLLR & $1,323.6910$ & 662.8528 & $1,323.7147$ & 662.8646 & 2 \\
\hline & f14-23, EVLNENLLRF & $1,245.6467$ & 623.8306 & $1,245.6718$ & 623.8431 & 2 \\
\hline & f15-23, VLNENLLRF & $1,116.6080$ & 559.3113 & $1,116.6292$ & 559.3218 & 2 \\
\hline & f24-36, FVAPFPEVFGKEK & $1,493.7756$ & 498.9325 & $1,493.7919$ & 498.9379 & 3 \\
\hline & f24-35, FVAPFPEVFGKE & $1,365.6743$ & 683.8444 & $1,365.6969$ & 683.8557 & 2 \\
\hline & f179-199, FSDIPNPIGSENSEKTTMPLW & $2,378.0972$ & 793.7063 & $2,378.1101$ & 793.7106 & 3 \\
\hline \multirow{2}{*}{$\kappa-\mathrm{CN}$} & f40-54, LNYYQQKPVALINNQ & $1,804.9138$ & 903.4642 & 1.804 .9471 & 903.4809 & 2 \\
\hline & f55-72, FLPYPYYAKPAAVRSPAQ & $2,038.0420$ & 680.3546 & $2,038.0676$ & 680.3632 & 3 \\
\hline
\end{tabular}

${ }^{1} \mathrm{MW}=$ molecular weight; $\mathrm{m} / z=$ mass to change ratio, where $z=$ number of positively charged ions.

upon cell lysis and no other cell wall-bound peptidase activity (Miclo et al., 2012). In contrast, in the present work, peptidase activity was detected in the whole-cell fraction without cell lysis during incubation, which was confirmed using Lys-pNA. Thus, in B. longum, casein could be hydrolyzed by this potential CEP or another proteolytic system.

The hydrophilic region at the $\mathrm{N}$-terminal region on $\beta$-casein was resistant to hydrolysis by $B$. longum (Figure 4). This observation was also made in previous studies showing that the hydrophobic region (especially the C-terminal region) was more accessible to the CEP of Strep. thermophilus (Miclo et al., 2012) and Lb. helveticus (Sadat-Mekmene et al., 2011).

In the case of $\alpha_{\mathrm{S} 1}$-casein, 12 peptides were generated by the fermentation of $B$. longum. The $\mathrm{N}$-terminal region was more accessible to hydrolysis by this strain (Figure $4)$. The $\alpha_{\mathrm{S} 1}$-casein structure is composed of 4 parts $(\mathrm{Ku}-$ mosinski et al., 1993): (1) hydrophilic region (f1-12), (2) hydrophobic region (f13-40), (3) hydrophilic region (to residue 100), (4) hydrophobic region (f100-199). In the present study, $\alpha_{\mathrm{S} 1}$-casein was degraded to a greater extent in the hydrophobic region (f8-35) than in the hydrophilic region, and only 1 peptide was generated in the C-terminal hydrophobic region (f179-199), indicating high resistance in the region of residues $40-175$ and residues 181-199. This was similar to the results of Miclo et al. (2012), who reported that the region of residues $1-40$ is most susceptible to hydrolysis, whereas the region 41-91 is very resistant to hydrolysis. This observation on the accessibility of each region is not consistent with that of $\beta$-casein in the present study.

Only 2 peptides were generated from the $\mathrm{N}$-terminal region of $\kappa$-casein in the present work. No peptide was generated from the glycomacropeptide (f106-169) region at the C-terminus. Glycan chains may protect against hydrolysis in this region conferring hydrophilic properties and negative charge (increase in electrostatic repulsions; Zahraa, 2010).

No peptides were identified from $\alpha_{S_{2}}$-casein in this fraction. $\alpha_{\mathrm{S}_{2}}$-Casein could be more resistant to hydrolysis by $B$. longum due to the formation of a tetrameric 

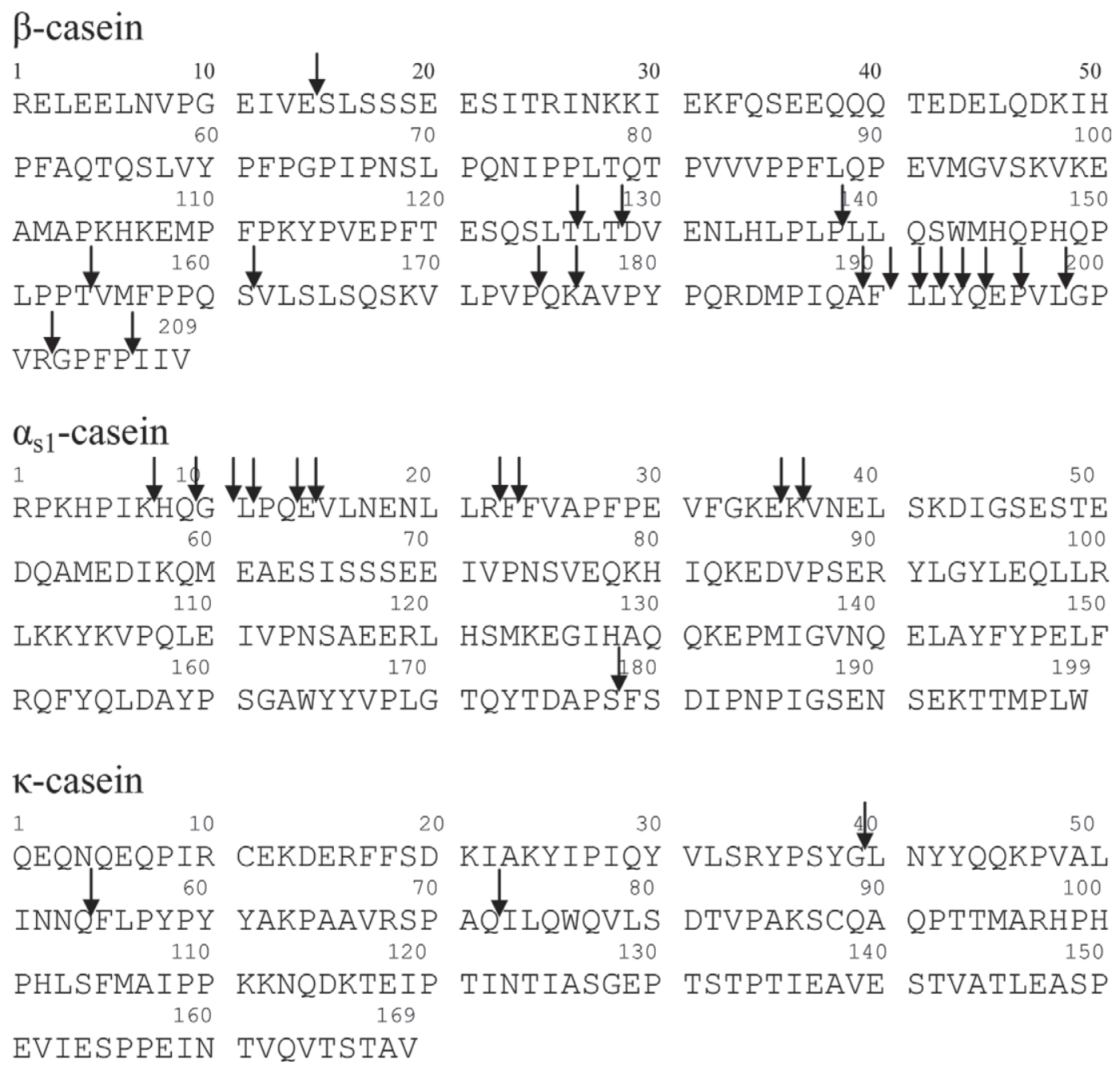

Figure 4. Cleavage region of peptide bonds on bovine $\beta-, \alpha_{S_{1}-}$, and $\kappa$-caseins hydrolyzed after fermentation with Bifidobacterium longum KACC9156. The arrows indicate cleaved peptide bonds.

form of $\alpha_{\mathrm{S} 2^{-}}$casein in phosphate buffer ( $\mathrm{pH} 8.1$ ), providing protection in some regions (Tauzin et al., 2003). Investigation of the accessibility of regions containing protein structure seems to be an appropriate method to explain susceptibility to hydrolysis (Miclo et al., 2012).

\section{Potential Antioxidant Peptide in the $<3$ kDa Fraction}

In previous studies, antioxidant peptides have been investigated following the hydrolysis of individual caseins (Table 4). Milk proteins and fermented milk are well-known, food-based sources of natural antioxidants in the form of antioxidant peptides (Hayes et al., 2007). Díaz (2005) reported that casein hydrolysates are promising sources of natural antioxidants because they have potential free radical scavenging ability.
As shown in Table 4, 2 peptides, VLSLSQSKVLPVPQK and VLSLSQSKVLPVPQKAVPYPQRDMPIQA, among the peptides generated from $\beta$-casein identified through the analysis in this work exhibited antioxidant properties. These peptides contain the fragment $\beta$-casein (f185-190), VLPVPQ, which has antioxidant activity. This is consistent with studies by Hayes et al. (2007) and Hernandez-Ledesma et al. (2004), who reported that the peptide $\beta$-casein (f181-190), SQSKVLPVPQ, may contain a potential antioxidant property, given that this peptide contains the fragment $\beta$-casein (f185-190), VLPVPQ, which was previously identified from Spanish commercial fermented milk with Lactobacillus helveticus and Saccharomyces cerevisiae. Rival et al. (2001b) reported that the peptide VLSLSQSKVLPVPQKAVPYPQRDMPIQA, derived from milk protein after trypsin treatment and containing the pep- 
Table 4. Antioxidant peptides identified from bovine milk caseins in the literature

\begin{tabular}{|c|c|c|c|}
\hline Casein & Sequence & Identification & Reference \\
\hline \multirow[t]{3}{*}{$\beta-\mathrm{CN}$} & f98-105, VKEAMAPK & $\mathrm{ND}^{1}$ & $\begin{array}{l}\text { Rival et al., 2001b; Gupta et al., 2010; } \\
\text { Miclo et al.. } 2012\end{array}$ \\
\hline & f184-190, VLPVPQ & $\begin{array}{l}\text { VLSLSQSKVLPVPQK } \\
\text { VLSLSQSKVLPVPQKA } \\
\text { VPYPORDMPIOA }\end{array}$ & Hernández-Ledesma et al., 2004 \\
\hline & f177-183, AVPYPQR & $\begin{array}{l}\text { VLSLSQSKVLPVPQKA } \\
\text { VPYPQRDMPIQA }\end{array}$ & Rival et al., 2001a \\
\hline$\alpha_{\mathrm{S}^{-}} \mathrm{CN}$ & f144-149, YFYPEL & ND & Suetsuna et al., 2000; Miclo et al., 2012 \\
\hline$\alpha_{\mathrm{S}_{2}}-\mathrm{CN}$ & f202-207, PYVRYL & ND & $\begin{array}{l}\text { Lopez-Expósitó et al., 2007; } \\
\text { Miclo et al., } 2012\end{array}$ \\
\hline
\end{tabular}

tide $\beta$-casein (f177-183), AVPYPQR, has antioxidant activity on the basis of its DPPH scavenging activity. Thus, antioxidant peptide(s) could be generated from $\beta$-casein by $B$. longum.

In addition, the peptide $\beta$-casein (f98-105), VKEAMAPK, has been reported to have antioxidant properties. Recently, PrtS of Strep. thermophilus 4F44 has been shown to generate this fragment (Miclo et al., 2012). In Cheddar cheese inoculated with Lactobacillus casei ssp. casei 300, this fragment was generated during aging (Gupta et al., 2010). In a synthetic peptide $\beta$-casein (f98-105), the antioxidant properties were determined through enzymatically and chemically induced oxidation of the linoleic acid oxidation system, hemoglobin-catalyzed oxidation of linoleic acid, hydroperoxide oxidation, DPPH assay, and measurement of $\mathrm{Fe}^{2+}$ chelating activity (Rival et al., 2001a).

For $\alpha_{S_{1}}$-casein, the peptide $\alpha_{S_{1}}$-casein (f144-149), YFYPEL, showed strong superoxide anion radical scavenging activity. This peptide was isolated from pepsic hydrolysate and exhibited superoxide anion scavenging activity and DPPH radical and hydroxyl radical scavenging activities (Suetsuna et al., 2000). The fragment PYVRYL from ovine $\alpha_{S 2}$-casein has antioxidant properties and corresponds to the $\alpha_{\mathrm{S}_{2}}$-casein (f202-207) fragment (PYVRYL) from bovine $\alpha_{\mathrm{S} 2}$-casein generated after hydrolysis by the cell envelope protease PrtS of Strep. thermophilus PB385 (Miclo et al., 2012) and trypsin (Lopez-Expósitó et al., 2007).

However, no antioxidant peptides were detected from $\alpha_{S 1^{-}}$and $\kappa$-casein in the present results. This could be explained by differences in protein degradation with or without proteases during incubation between LAB and Bifidobacterium.

\section{CONCLUSIONS}

In the present study, antioxidant activity in caseinderived peptides obtained from fermentation with $B$. longum was detected using ABTS free radical scaveng- ing activity and total phenolic peptide measurements. Two peptides having antioxidant activity were identified through MS analysis. Based on these results, further study of the $<3 \mathrm{kDa}$ fraction of each casein and fermented milk is needed to investigate and identify novel peptides with antioxidant properties and to screen bioactive peptides generated by $B$. longum that have other functions, such as antihypertensive, antimutagenic, and immunomodulant peptides.

\section{ACKNOWLEDGMENTS}

This study was sponsored by National Institute of Animal Science (NIAS) research project (PJ0085852013) of Rural Development Administration of Korea (RDA). The author Oun Ki Chang participated in this project as a postdoctoral researcher. The authors acknowledge J. Lee and researcher H.-J. Choi (both from the National Instrumentation Center for Environmental Management, Seoul National University, Seoul, Korea) for MS analysis.

\section{REFERENCES}

Agerholm-Larsen, L., A. Raben, N. Haulrik, A. S. Hansen, M. Manders, and A. Astrup. 2000. Effect of 8 weeks intake of probiotic milk products on risk factors for cardiovascular diseases. Eur. J. Clin. Nutr. 54:288-297.

Al-Sheraji, S. H., A. Ismail, M. Y. Manap, S. Mustafa, R. M. Yusof, and F. A. Hassan. 2012. Hypocholesterolaemic effect of yoghurt containing Bifidobacterium pseudocatenulatum G4 or Bifidobacterium longum BB536. Food Chem. 135:356-361.

Alhaj, O. A., A. D. Kanekanian, A. C. Peters, and A. S. Tatham. 2010. Hypocholesterolaemic effect of Bifidobacterium animalis ssp. lactis (Bb12) and trypsin casein hydrolysate. Food Chem. 123:430-435.

Arnao, M. B. 2000. Some methodological problems in the determination of antioxidant activity using chromogen radicals: A practical case. Trends Food Sci. Technol. 11:419-421.

Arunachalam, K. D. 1999. Role of bifidobacteria in nutrition, medicine and technology. Nutr. Res. 19:1559-1597.

Beckman, K. B., and B. N. Ames. 1998. The free radical theory of aging matures. Physiol. Rev. 78:547-581.

Cha, M. K., D. K. Lee, H. M. An, S. W. Lee, S. H. Shin, J. H. Kwon, K. J. Kim, and N. J. Ha. 2012. Antiviral activity of Bifidobacterium adolescentis SPM1005-A on human papillomavirus type 16 . BMC Med. 10:72-77. 
Chang, O. K., C. Perrin, W. Galia, F. Saulnier, L. Miclo, E. Roux, A. Driou, G. Humbert, and A. Dary. 2012. Release of the cellenvelope protease PrtS in the growth medium of Streptococcus thermophilus 4F44. Int. Dairy J. 23:91-98.

Collins, M. D., and G. R. Gibson. 1999. Probiotics, prebiotics, and synbiotics: Approaches for modulating the microbial ecology of the gut. Am. J. Clin. Nutr. 69:1052S-1057S.

Davidson, R. H., S. E. Duncan, C. R. Hackney, W. N. Eigel, and J. W. Boling. 2000. Probiotic culture survival and implications in fermented frozen yogurt characteristics. J. Dairy Sci. 83:666-673.

Díaz, M. 2005. Antioxidant properties of caseinophosphopeptides and casein hydrolysates. PhD Thesis. University of Massachusetts, Amherst.

Egito, A. S., L. Miclo, C. López, A. Adam, J. M. Girardet, and J. L. Gaillard. 2002. Separation and characterization of mares' milk $\alpha_{s 1^{-}}, \beta-, \kappa$-caseins, gamma-casein-like, and proteose peptone component 5-like peptides. J. Dairy Sci. 85:697-706.

Espeche Turbay, M. B., D. E. Savoy, G. Giori, and E. M. Hebert. 2009. Release of the cell-envelope-associated proteinase of Lactobacillus delbrueckii subspecies lactis CRL 581 is dependent upon $\mathrm{pH}$ and temperature. J. Agric. Food Chem. 57:8607-8611.

Fernandez-Espla, M. D., P. Garault, V. Monnet, and F. Rul. 2000. Streptococcus thermophilus cell wall-anchored proteinase: Release, purification, and biochemical and genetic characterization. Appl. Environ. Microbiol. 66:4772-4778.

Gilbert, C., D. Atlan, B. Blanc, R. Portailer, J. E. Germond, L. Lapierre, and B. Mollet. 1996. A new cell surface proteinase: Sequencing and analysis of the prtB gene from Lactobacillus delbrueckii ssp. bulgaricus. J. Bacteriol. 178:3059-3065.

Gupta, N., K. K. Hixson, D. E. Culley, R. D. Smith, and P. A. Pevzner. 2010. Analyzing protease specificity and detecting in vivo proteolytic events using tandem mass spectrometry. Proteomics 10:2833-2844.

Ham, J. S., T. Lee, M. J. Byun, K. T. Lee, M. K. Kim, G. S. Han, S. G. Jeong, M. H. Oh, D. H. Kim, and H. Kim. 2011. Complete genome sequence of Bifidobacterium longum ssp. longum KACC 91563. J. Bacteriol. 193:5044.

Hayes, M., R. P. Ross, G. F. Fitzgerald, and C. Stanton. 2007. Putting microbes to work: Dairy fermentation, cell factories and bioactive peptides. Part II: Bioactive peptide functions. Biotechnol. J. 2:435-449.

Hernández-Ledesma, B., L. Amigo, M. Ramos, and I. Recio. 2004. Angiotensin converting enzyme inhibitory activity in commercial fermented products. Formation of peptides under simulated gastrointestinal digestion. J. Agric. Food Chem. 52:1504-1510.

Holt, C., and L. Sawyer. 1993. Caseins as rheomorphic proteins: Interpretation of primary and secondary structures of the $\alpha_{\mathrm{s1}}{ }^{-}, \beta$ - and K-caseins. J. Chem. Soc. Faraday Trans. 89:2683-2692.

Janer, C., F. Arigoni, B. H. Lee, C. Peláez, and T. Requena. 2005. Enzymatic ability of Bifidobacterium animalis ssp. lactis to hydrolyze milk proteins: Identification and characterization of endopeptidase O. Appl. Environ. Microbiol. 71:8460-8465.

Juillard, V., H. Laan, E. R. Kunji, C. M. Jeronimus-Stratingh, A. P. Bruins, and W. N. Konings. 1995. The extracellular PI-type proteinase of Lactococcus lactis hydrolyzes beta-casein into more than one hundred different oligopeptides. J. Bacteriol. 177:3472-3478.

Kalliomaki, M., S. Salminen, H. Arvilommi, P. Kero, P. Koskinen, and E. Isolauri. 2001. Probiotics in primary prevention of atopic disease: A randomised placebo-controlled trial. Lancet 357:10761079.

Kok, J., K. J. Leenhouts, A. J. Haandrikman, A. M. Ledeboer, and G. Venema. 1988. Nucleotide sequence of the cell wall proteinase gene of Streptococcus cremoris Wg2. Appl. Environ. Microbiol. 54:231-238.

Korhonen, H. 2009. Milk-derived bioactive peptides: From science to applications. J. Funct. Food 1:177-187.

Kullisaar, T., E. Songisepp, M. Mikelsaar, K. Zilmer, T. Vihalemm, and M. Zilmer. 2003. Antioxidative probiotic fermented goats' milk decreases oxidative stress-mediated atherogenicity in human subjects. Br. J. Nutr. 90:449-456.
Kumosinski, T. F., E. M. Brown, and H. M. Farrell Jr. 1993. Threedimensional molecular modeling of bovine caseins: An energy-minimized $\kappa$-casein structure. J. Dairy Sci. 76:931-945.

Leahy, S. C., D. G. Higgins, G. F. Fitzgerald, and D. van Sinderen. 2005. Getting better with bifidobacteria. J. Appl. Microbiol. 98:1303-1315.

Lopez-Expósitó, I., A. Quiros, L. Amigo, and I. Recio. 2007. Casein hydrolysates as a source of antimicrobial, antioxidant and antihypertensive peptides. Dairy Sci. Technol. 87:241-249.

Martín-Diana, A. B., C. Janer, C. Peláez, and T. Requena. 2003. Development of a fermented goat's milk containing probiotic bacteria. Int. Dairy J. 13:827-833.

Mattarelli, P., and B. Biavati. 1999. Influence of amino acid requirement on the growth of Bifidobacterium globosum strains. New Microbiol. 22:69-72.

McBrearty, S., R. P. Ross, G. F. Fitzgerald, J. K. Collins, J. M. Wallace, and C. Stanton. 2001. Influence of two commercially available bifidobacteria cultures on cheddar cheese quality. Int. Dairy J. 11:599-610.

Miclo, L., E. Roux, M. Genay, E. Brusseaux, C. Poirson, N. Jameh, C. Perrin, and A. Dary. 2012. Variability of hydrolysis of $\beta-$, $\alpha$ s1-, and as2-caseins by 10 strains of Streptococcus thermophilus and resulting bioactive peptides. J. Agric. Food Chem. 60:554-565.

Pastar, I., I. Tonic, N. Golic, M. Kojic, R. van Kranenburg, M. Kleerebezem, L. Topisirovic, and G. Jovanovic. 2003. Identification and genetic characterization of a novel proteinase, PrtR, from the human isolate Lactobacillus rhamnosus BGT10. Appl. Environ. Microbiol. 69:5802-5811.

Prasanna, P. H. P., A. S. Grandison, and D. Charalampopoulos. 2012 Effect of dairy-based protein sources and temperature on growth, acidification and exopolysaccharide production of Bifidobacterium strains in skim milk. Food Res. Int. 47:6-12.

Re, R., N. Pellegrini, A. Proteggente, A. Pannala, M. Yang, and C. Rice-Evans. 1999. Antioxidant activity applying an improved ABTS radical cation decolorization assay. Free Radic. Biol. Med. 26:1231-1237.

Rival, S. G., C. G. Boeriu, and H. J. Wichers. 2001a. Caseins and casein hydrolysates. 2. Antioxidative properties and relevance to lipoxygenase inhibition. J. Agric. Food Chem. 49:295-302.

Rival, S. G., S. Fornaroli, C. G. Boeriu, and H. J. Wichers. 2001b. Caseins and casein hydrolysates. 1. Lipoxygenase inhibitory properties. J. Agric. Food Chem. 49:287-294.

Ruiz, L., B. Sánchez, C. G. de los Reyes-Gavilán, M. Gueimonde, and A. Margolles. 2009. Coculture of Bifidobacterium longum and Bifidobacterium breve alters their protein expression profiles and enzymatic activities. Int. J. Food Microbiol. 133:148-153.

Saavedra, J. M., A. Abi-Hanna, N. Moore, and R. H. Yolken. 2004 Long-term consumption of infant formulas containing live probiotic bacteria: Tolerance and safety. Am. J. Clin. Nutr. 79:261-267.

Sadat, L., C. Cakir-Kiefer, M. A. N'Negue, J. L. Gaillard, G. M. Girardet, and L. Miclo. 2011. Isolation and identification of antioxidative peptides from bovine $\alpha$-lactalbumin. Int. Dairy J. 21:214-221.

Sadat-Mekmene, L., L. Jardin, C. Corre, D. Mollé, R. Richoux, M. M. Delage, S. Lortal, and V. Gagnaire. 2011. Simultaneous presence of PrtH and PrtH2 proteinases in Lactobacillus helveticus strains improves breakdown of the pure $\alpha_{\mathrm{S}_{1}}$-casein. Appl. Environ. Microbiol. $77: 179-186$.

Savijoki, K., H. Ingmer, and P. Varmanen. 2006. Proteolytic systems of lactic acid bacteria. Appl. Microbiol. Biotechnol. 71:394-406.

Shahbal, S., D. Hemme, and P. Renault. 1993. Characterization of a cell envelope-associated proteinase activity from Streptococcus thermophilus H-strains. Appl. Environ. Microbiol. 59:177-182.

Singleton, V. L., and J. A. Rossi Jr. 1965. Colorimetry of total phenolics with phosphomolybdic-phosphotungstic acid reagents. Am. J. Enol. Vitic. 16:144-158.

Suetsuna, K., H. Ukeda, and H. Ochi. 2000. Isolation and characterization of free radical scavenging activities peptides derived from casein. J. Nutr. Biochem. 11:128-131.

Tauzin, J., L. Miclo, S. Roth, D. Mollé, and J. L. Gaillard. 2003. Tryptic hydrolysis of bovine $\alpha_{\mathrm{s} 2}$-casein: Identification and release kinetics of peptides. Int. Dairy J. 13:15-27. 
Wolff, S. P., Z. Y. Jiang, and J. V. Hunt. 1991. Protein glycation and oxidative stress in diabetes mellitus and ageing. Free Radic. Biol. Med. 10:339-352.

Yang, S. A., N. K. Im, Y. J. Ji, D. C. Yoo, K. H. Jhee, and I. S. Lee 2008. Radical scavenging and inhibition of platelet function by a polyphenol-rich fraction from Salvia miltiorrhiza Bunge. Open Natural Prod. J. 1:7-13.

Yin, Y. N., Q. F. Yu, N. Fu, X. W. Liu, and F. G. Lu. 2010. Effects of four Bifidobacteria on obesity in high-fat diet induced rats. World J. Gastroenterol. 16:3394-3401.

Yu, M. H., H. G. Im, H. J. Lee, Y. J. Ji, and I. S. Lee. 2006. Components and their antioxidative activities of methanol extracts from sarcocarp and seed of Zizyphus jujuba var. inermis Rehder. Korean J. Food Sci. Technol. 38:128-134.

Yu, W. K., J. Y. Kim, K. Y. Lee, and T. R. Heo. 2002. High cell density cultivation of Bifidobacterium longum using a calcium carbonate-alginate beads system. J. Microbiol. Biotechnol. 12:444-448. Zahraa N. 2010. Le peptide k-CN(f106-109) du lait: Propriétés nutritionnelles, biologiques et techno-fonctionnelles. Mémoire de M2, UHP Nancy 1. Université Henri Poincaré (UHP) Nancy 1, Nancy, France. 